\title{
Epidemiological Investigation of the Peste des Petits Ruminants Outbreaks in Karnataka, India
}

\section{Amitha Reena Gomes ${ }^{1}$, Sonnahallipura Munivenkatappa Byregowda ${ }^{1}$, Belamaranahally MuniveerappaVeeregowda ${ }^{2}$, Doddamane Rathnamma ${ }^{2}$, Basavegowdanadoddi Marinaik Chandranaik ${ }^{1}$, Beechagondahalli Papanna Shivashankar ${ }^{1}$, Karabasappa Choudapur Mallinath $^{1}$, Vinayagamurthy Balamurugan ${ }^{3 *}$}

${ }^{1}$ Institute of Animal Health and Veterinary Biologicals, KVAFSU, Hebbal, Bengaluru-560024, Karnataka, India; ${ }^{2}$ Department of Microbiology, Veterinary College, KVAFSU, Hebbal, Bengaluru-560024, Karnataka, India; ${ }^{3}$ Indian Council of Agricultural Research-National Institute of Veterinary Epidemiology and Disease Informatics (ICAR-NIVEDI), Post Box No. 6450, Yelahanka, Bengaluru-560064, Karnataka, India.

\begin{abstract}
The present study reports the epidemiological and virological investigations of the twelve different outbreaks of Peste des Petits Ruminants (PPR) in goats and sheep flocks with considerable morbidity and mortality recorded from different places of Karnataka state in India during 2014-2015. Clinical samples were collected from the affected flocks or villages for laboratory investigation along with epidemiological parameters. The PPR virus (PPRV) antigen and its genome were detected in the infected tissues or swab materials by sandwich enzyme-linked immunosorbent assay (s-ELISA) and reverse transcription-polymerase chain reaction (RT-PCR). The significant epidemiological parameters recorded include young animals being severely affected than adult animals, which showed symptoms suggestive of PPR and changing pattern of disease in term of severity of gross lesions and clinical signs. The source of infection was traced back to introduction of new animals from other flocks or from other states. Despite regular vaccination of sheep and goats in the state, under National Control Programme on PPR (NCP-PPR), outbreaks need to be carefully monitored due mainly to production losses in small ruminants.
\end{abstract}

Keywords $\mid$ Peste des Petits Ruminants, Sheep and goats, Epidemiology, Outbreaks, Karnataka, India

Editor | V. Gnanavel (M.V.Sc., Ph.D), Scientist, Virology Division, ICAR-Indian Veterinary Research Institute (ICAR-IVRI), Mukteswar, Nainital, Uttarakhand, India

Special Issue | 2,2016 "Emerging Challenges and Opportunities in Veterinary Research for Improvement of Animal Health".

Received | February 16, 2016; Revised | March 14, 2016; Accepted | March 15, 2016; Published | April 23, 2016

"Correspondence | Vinayagamurthy Balamurugan, Senior Scientist, ICAR-NIVEDI, Post Box No. 6450, Yelahanka, Bengaluru-560064, Karnataka, India; Email: balavirol@gmail.com

Citation | Gomes AR, Byregowda SM, Veeregowda BM, Rathnamma D, Chandranaik BM, Shivashankar BP, Mallinath KC, Balamurugan V (2016). Epidemiological investigation of the Peste des Petits Ruminants outbreaks in Karnataka, India. Adv. Anim. Vet. Sci. 4(2s): 27-33.

DOI | http://dx.doi.org/10.14737/journal.aavs/2016/4.2s.27.33

ISSN (Online) | 2307-8316; ISSN (Print) | 2309-3331

Copyright $(92016$ Gomes et al. This is an open access article distributed under the Creative Commons Attribution License, which permits unrestricted use, distribution, and reproduction in any medium, provided the original work is properly cited.

\section{INTRODUCTION}

$\mathrm{P}$ este des Petits Ruminants (PPR) is a contagious disease of goats and sheep caused by PPR virus (PPRV), a member of genus morbillivirus of family Paramyxoviridae. The disease is characterized by fever, stomatitis, diarrhoea, pneumonia and sometimes death (Gargadennec and $\mathrm{La}^{-}$ lanne, 1942). The disease has a major economic importance listed in OIE and mainly reported from Africa, Middle East and Indian Subcontinent. It is a major hurdle in small ruminant farming owing to its mortality and loss in pro- duction there by affecting livelihood of small and marginal farmers.

In India, PPR was first recorded in 1987 from Tamil Nadu (Shaila et al., 1989) and it continued to be reported only from the Southern India until 1994. Later on, number of PPR outbreaks were reported from the northern states of India (Nanda et al., 1996) with a solitary report in Indian buffalo in southern state (Govindarajan et al., 1997). Now, PPR is enzootic in India, and outbreaks occur in sheep and goats regularly throughout the year. It is a major constraint 
in small ruminant production incurring huge economic losses (estimated to be INR 1,800 million (US\$39 million)) annually in terms of morbidity, mortality, productivity losses with trade restriction (Venkataramanan et al., 2005).

For the effective control of PPR, there is a need for base line epidemiological data on the disease prevalence in population, accurate diagnostic methods, and effective and timely vaccination of the susceptible population. Institute of Animal Health and Veterinary Biologicals (IAH \& VB) is a premier research Institute under Karnataka Veterinary, Animal and Fisheries Sciences University (KVAFSU), Bidar in the state of Karnataka involved in production of vaccines, investigation of disease outbreaks besides carrying out basic research in the field of veterinary health. The state is under regular vaccination programme against the disease since 2005 and pulse polio mode of vaccination under national control programme on PPR (NCP-PPR) from 2011. In spite of vaccination, outbreaks of PPR are being reported sporadically in some pockets of the state. Thus the current study was undertaken to investigate outbreak status in the state due to the efficiency of the vaccine and / or vaccination and also to describe the epidemiological and virological investigations of the confirmed sporadic PPR outbreaks reported in different parts of Karnataka state of India during 2014-2015 based on the virus isolation and detection of antigen, antibody, and genome of the PPRV in the clinical samples collected during the outbreak investigations.

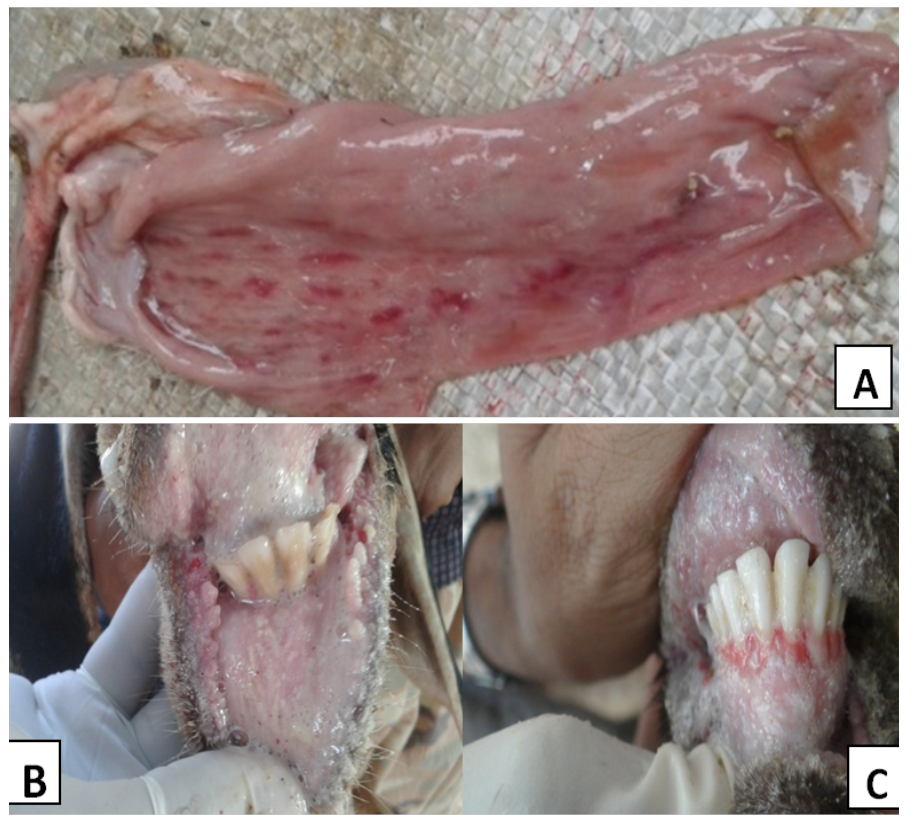

Figure 1: PPR affected animals showing

A) Post-mortem lesions streaks of congestion and haemorrhages (Zebra marking) on the mucosal folds of intestine; B) Necrotic ulceration/stomatitis with bran like deposits in the oral cavity; C) Ulceration and bleeding in the gums

\section{MATERIALS AND METHODS}

\section{EPidemiological Observations}

The outbreaks of PPR occurred in different villages of the state in local breeds of goats and sheep aged between three months to three years. All the affected animals in the flocks were showing symptoms of PPR. Clinical signs observed included anorexia, high fever, discharge from the nostrils, coughing, sneezing or wheezing, respiratory distress, salivation, ulcerations on gums, dental pads, diarrhoea or severe diarrhoea and death (Figure 1). In some cases even abortion was noticed in pregnant animals. The post-mortem lesions were characterized by inflammatory and necrotic lesions in the oral cavity and throughout the gastrointestinal tract. The carcass was often emaciated and/or dehydrated, and had the evidence of diarrhoea and serous or mucopurulent oculo-nasal discharges. Hemorrhagic streaks and erosions were common in the intestinal tracts (Figure 1). "Zebra stripes" or "tiger stripes" of congestion, haemorrhage or darkened tissue were seen in the posterior part of the colon on the mucosal folds. The lymph nodes, particularly those associated with the respiratory and gastrointestinal tracts were generally congested, enlarged and oedematous.

\section{Clinical Materials}

Clinical samples were collected or received through veterinarians from the twelve different outbreaks in goats and sheep by the disease investigation team or regional laboratories and were subjected for laboratory investigations during the period from October, 2014 to December, 2015. Clinical samples such as blood, serum, nasal / oral / ocular / rectal swabs and post-mortem samples namely spleen, lymph nodes, lung, liver etc., were collected from affected, non-affected or in contact and dead animals with different age groups during the investigation (Table 1).

\section{ELISA AND RT-PCR Assays}

All the clinical samples were initially screened by sandwich ELISA (s-ELISA) (Singh et al., 2004a) and reverse transcription polymerase chain reaction (RT-PCR) assays for the detection of PPRV antigen and its genome respectively. The total RNA was extracted from clinical materials by using RNA easy kit (RNeasy ${ }^{\circledR}$ Minikit Qiagen Inc, Valencia, CA, USA), and RT-PCR was performed using Qiagen Revert Aid First Strand cDNA Synthesis Kit for first strand synthesis and subsequently PCR was performed using virus specific reported primer sets (Forsyth and Barrett, 1995; Couacy et al., 2002; Balamurugan et al., 2006) using PCR Master mix reagents (Qiagen Inc, Valencia, CA, USA). The serum samples were tested for the presence of PPRV-specific antibodies by using competitive enzyme-linked immunosorbent assay (c-ELISA) kit from Indian Veterinary Research Institute (Singh et al., 2004b). 
Table 1: Epidemiological details of the samples and their test results screened for Peste des Petits Ruminants virus antigen, genome and antibodies

\begin{tabular}{|c|c|c|c|c|c|c|c|c|c|c|}
\hline \multirow{2}{*}{$\begin{array}{l}\text { Name of the village, } \\
\text { Taluk and District }\end{array}$} & \multirow{2}{*}{$\begin{array}{l}\text { Species } \\
\text { affected }\end{array}$} & \multirow{2}{*}{$\begin{array}{l}\text { Mor- } \\
\text { bidity }\end{array}$} & \multirow{2}{*}{$\begin{array}{l}\text { Mor- } \\
\text { tality }\end{array}$} & \multirow{2}{*}{$\begin{array}{l}\text { Case } \\
\text { fatality } \\
\text { rate }\end{array}$} & \multirow{2}{*}{$\begin{array}{l}\text { Clinical specimens } \\
\text { collected }\end{array}$} & \multirow{2}{*}{$\begin{array}{l}\text { No. of } \\
\text { samples } \\
\text { screened }\end{array}$} & \multicolumn{3}{|c|}{ No. of samples positive in } & \multirow{2}{*}{$\begin{array}{l}\text { Isola- } \\
\text { tion }\end{array}$} \\
\hline & & & & & & & sELISA & cELISA & RT-PCR & \\
\hline $\begin{array}{l}\text { Devamachahalli, Tav- } \\
\text { arekere Hobli, Banga- } \\
\text { lore South Taluk }\end{array}$ & $\begin{array}{l}\text { Sheep } \\
\text { (Bannur } \\
\text { Breed) }\end{array}$ & 44 & 36 & 81.81 & $\begin{array}{l}\text { Nasal/ Faecal } \\
\text { swabs }\end{array}$ & 4 & 4 & - & 4 & + \\
\hline $\begin{array}{l}\text { Dyavasandra, } \\
\text { Hoskote Taluk Taluk, } \\
\text { Kolar District }\end{array}$ & Sheep & 20 & 6 & 30 & $\begin{array}{l}\text { Nasal / Faecal / } \\
\text { Oral swab Serum, } \\
\text { Spleen, lymphnode }\end{array}$ & 8 & 8 & 5 & 8 & - \\
\hline $\begin{array}{l}\text { Agasavalli-Hosur } \\
\text { Village, Shimoga ta- } \\
\text { luk, Shimoga District }\end{array}$ & Sheep & 32 & 16.6 & 52.08 & $\begin{array}{l}\text { Nasal swab } \\
\text { Blood } \\
\text { Serum }\end{array}$ & 3 & 2 & 1 & 2 & - \\
\hline $\begin{array}{l}\text { Gubbi, } \\
\text { Gubbi Taluk, Tumkur } \\
\text { District }\end{array}$ & Sheep & 26.66 & 16.66 & 62.5 & $\begin{array}{l}\text { Lung, Liver } \\
\text { Heart, Kidney In- } \\
\text { testinal Content }\end{array}$ & 2 & 2 & - & 2 & - \\
\hline $\begin{array}{l}\text { Kolnadu, Bantwal } \\
\text { Taluk, Dakshin } \\
\text { Kannada }\end{array}$ & Goats & 10 & 5 & 50 & $\begin{array}{l}\text { Nasal Swabs } \\
\text { Buccal swabs } \\
\text { Rectal swabs }\end{array}$ & 5 & 5 & - & 5 & - \\
\hline $\begin{array}{l}\text { Brammasandra, Sira } \\
\text { Taluk, Tumkur* }\end{array}$ & Goat & - & - & - & $\begin{array}{l}\text { Heart, Liver } \\
\text { Lung, Kidney } \\
\text { Intestine }\end{array}$ & 5 & 1 & - & 1 & - \\
\hline $\begin{array}{l}\text { Sira Taluk, Tumkur } \\
\text { District* }\end{array}$ & Sheep & - & - & - & Nasal swab & 1 & 1 & - & 1 & - \\
\hline $\begin{array}{l}\text { Tumkur, Tumkur } \\
\text { District }\end{array}$ & Sheep & 28.57 & 14.2 & 50 & $\begin{array}{l}\text { Nasal swab } \\
\text { Serum }\end{array}$ & 3 & 3 & 1 & 3 & - \\
\hline $\begin{array}{l}\text { Avverahalli village, } \\
\text { mandya Taluk, Man- } \\
\text { dya District }\end{array}$ & Sheep & 30 & 5 & 16.66 & $\begin{array}{l}\text { Bloood } \\
\text { Nasal swabs } \\
\text { Spleen } \\
\text { Lymph nodes }\end{array}$ & 4 & 4 & - & 4 & + \\
\hline $\begin{array}{l}\text { Ganjigunte village, } \\
\text { Sidlaghatta taluk } \\
\text { Chikballapur District }\end{array}$ & Sheep & 25 & 0 & 0 & $\begin{array}{l}\text { Nasal swab } \\
\text { Rectal swab }\end{array}$ & 2 & 2 & - & 2 & - \\
\hline $\begin{array}{l}\text { Shivajinagar, Banga- } \\
\text { lore Urban }\end{array}$ & Goats & 43.75 & 6.25 & 14.28 & $\begin{array}{l}\text { Blood } \\
\text { Nasal swab } \\
\text { Rectal swab }\end{array}$ & 2 & 2 & - & 2 & - \\
\hline $\begin{array}{l}\text { Kaggalipura village, } \\
\text { Bangalore South Ta- } \\
\text { luk, Bangalore Urban } \\
\text { District }\end{array}$ & Sheep & 9 & 3.38 & 37.5 & $\begin{array}{l}\text { Blood, nasal/fecal } \\
\text { swabs Mesenteric/ } \\
\text { Mediastinal lymph } \\
\text { nodes, lung samples }\end{array}$ & 3 & 3 & - & 3 & - \\
\hline
\end{tabular}

\section{Virus ISOLATION}

For virus isolation, swabs were collected in five $\mathrm{ml}$ of sterile Minimum Essential Medium with Earle's salts (GIBCO, Invitrogen) containing penicillin $(100 \mathrm{IU} / \mathrm{ml})$ and streptomycin $(100 \mu \mathrm{g} / \mathrm{ml})$. The samples which were otherwise positive by s-ELISA, were freeze thawed thrice and selected for virus isolation. Samples from same village and species were pooled and filtered using $0.45 \mu \mathrm{m}$ syringe filter. One to $1.5 \mathrm{ml}$ filtrate was inoculated onto Vero cell monolayer (80 per cent confluent) by pre-adsorption method. Cells were incubated at $37^{\circ} \mathrm{C}$ for one hour with intermit- tent shaking to allow adsorption of virus. The virus inoculum was then decanted and the infected cells were washed with Minimum Essential Medium (MEM) (serum free) and added with maintenance medium (2 per cent foetal calf serum with MEM) for further incubation at $37^{\circ} \mathrm{C}$ for 6-8 days with change of maintenance medium on alternate days. The monolayer was regularly observed for the appearance of cytopathic effects (CPE) and passaging of the virus continued until visible $\mathrm{CPE}$ observed in the infected cells. To investigate the specificity of the isolated virus, RT-PCR was performed on cell culture adapted isolates as 


\section{described earlier.}

\section{RESULTS AND DISCUSSION}

The results of clinical materials (Table 1) revealed that most samples from each of the outbreaks \{the location of which is depicted in an earth map with geo coordinates (Figure 2)\} were positive for PPRV antigen or its genome when tested by s-ELISA and RT-PCR assays (Figure 3). Further, the PPRV was successfully isolated from a few clinical specimens in Vero cells at passage level 4 to 6 at 5-6 days post infection (dpi) showed Characteristics CPE (Figure 4). The morbidity, mortality, and case fatality rates of disease in different outbreaks are set out in Table 1. Serum samples showed varying percentage inhibition from 2 to 75 for PPRV antibodies by c-ELISA.

PPR is endemic in India, with seroprevalence and mortality rates of 30-45 and 15-30 per cent respectively. Outbreaks are more common in sheep in South India and in goats in North India (Venkataramanan et al., 2005; Balamurugan et al., 2012). Karnataka state is situated between latitudes $11^{\circ} 40^{\prime}$ and $18^{\circ} 27^{\prime}$ and longitudes $74^{\circ} 50^{\prime}$ and $78^{\circ}$ $33^{\prime}$ in the centre of western peninsular India. It covers an area of 19.1 million hectares (Mha) and accounts for 5.8 per cent of the country's total geographic area. The disease is reported in the state since 1998 affecting large number of small ruminants during 2002 to 2006 (Hegde et al., 2009). Then onwards due to regular vaccination, the disease is on the phase of decline. Although the clinical signs and post-mortem findings are sufficient for tentative diagnosis of PPR in the endemic areas, yet the laboratory tests/ assays is essential for definitive confirmatory diagnosis. The clinical signs, post mortem findings and epidemiological observations clearly indicated the presence of PPR virus in the outbreaks investigated.

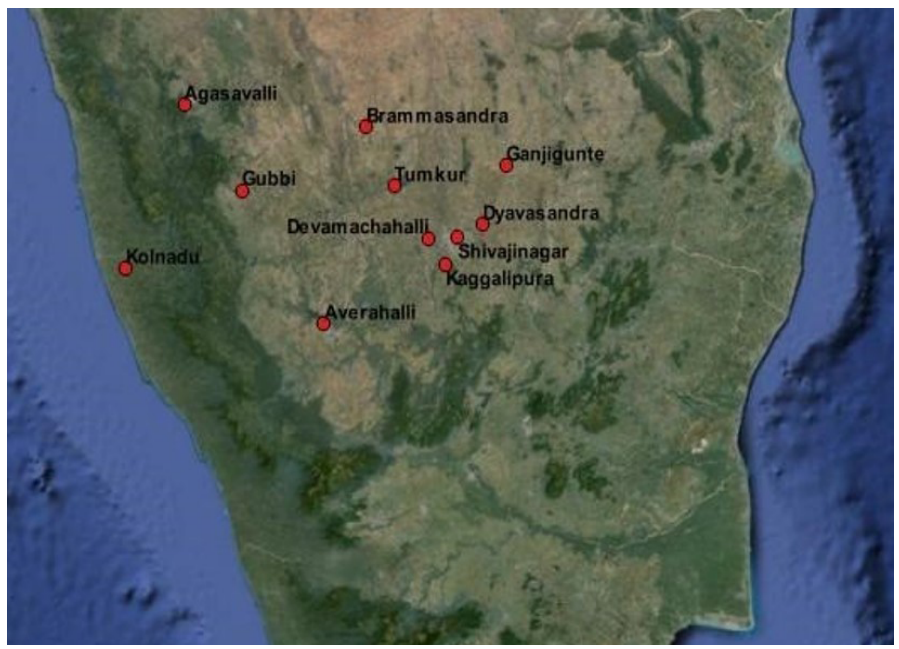

Figure 2: Google Earth map showing the location of outbreaks with geo coordinates carried out by using QGIS 4.12 version software

\section{$\begin{array}{lllllllllllllll}1 & 2 & 3 & 4 & 5 & 6 & 7 & 8 & 9 & 10 & 11 & 12 & 13 & 14 & 15\end{array}$}

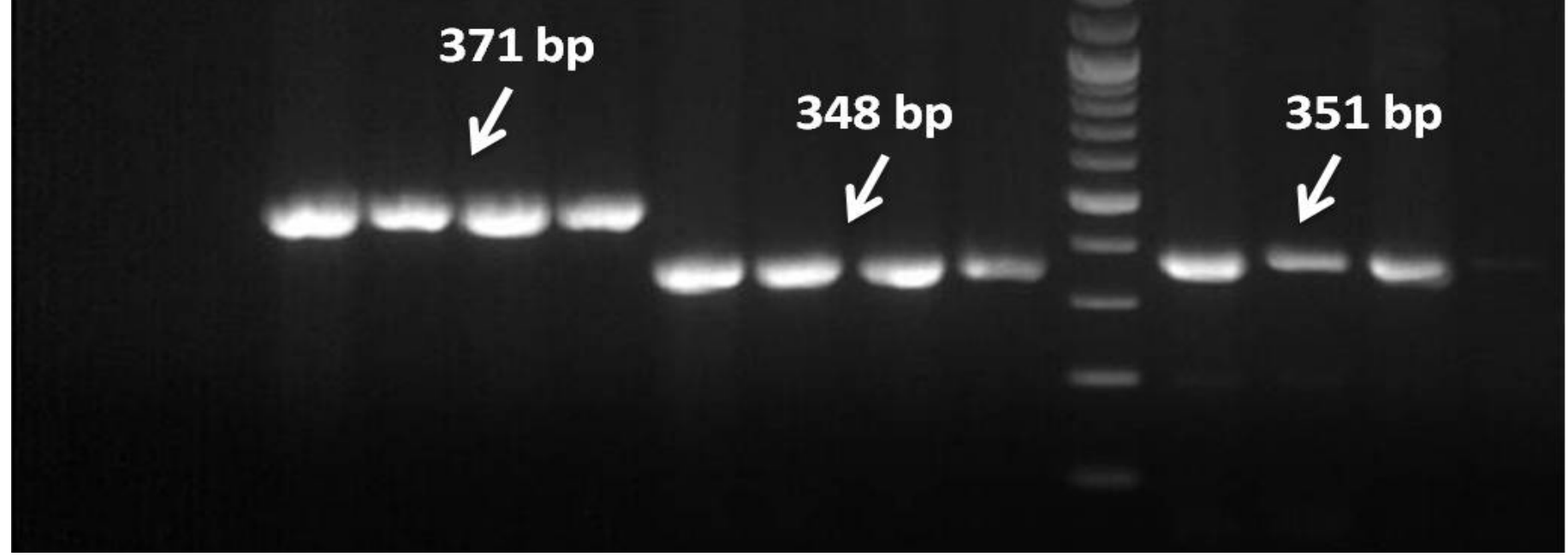

Figure 3: Detection of PPRV genome by RT-PCR using F (Lane: 3-6), NP1/NP2 (Lane: 7-10) and NP3/NP4 (Lane: 12-15) set of primers. Lane 1: Negative control; Lane 2: No template control and Lane 11: DNA 100bp ladder Marker 
Although, the origin of the disease could not be traced and exact source of the infection could not be ascertained, movement or introduction of animals purchased from the live market without proper vaccination details, history and failure to implement strict quarantine measures was attributed in many of these outbreaks. In most of these outbreaks, it was also observed / revealed that the animals were not vaccinated against the disease due to lack of awareness among the farmers. Similar sources of the disease have been implicated before (Muhammad et al., 2009; Muse et al., 2012). Movement of animals among the places is a common factor in animal trading. Subsequent contact of infected animals under transport stress might be the key factor leading to an outbreak.

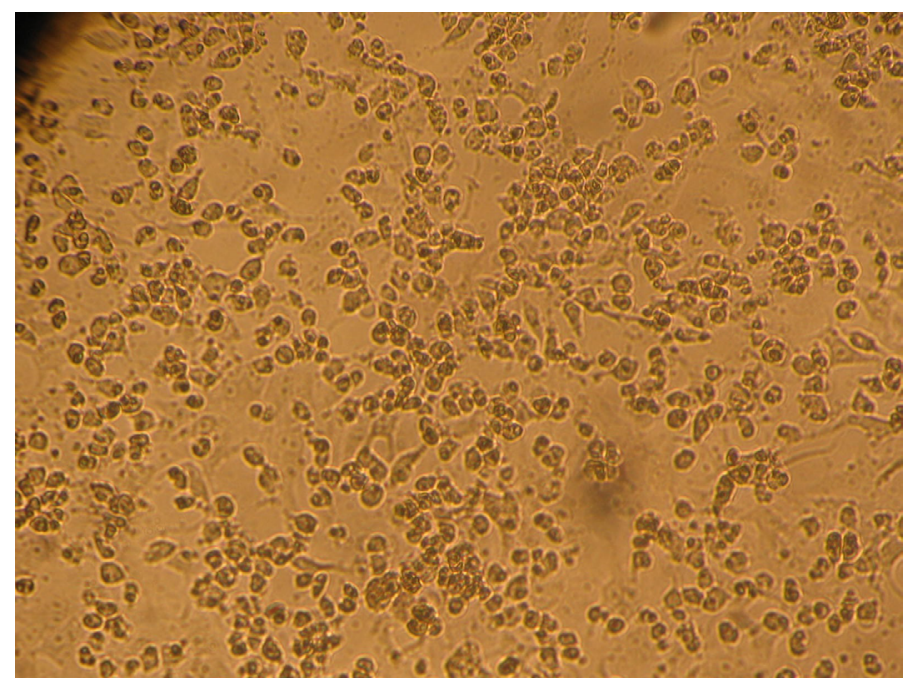

Figure 4: PPRV isolate (passage 6) infected Vero cells showing characteristic cytopathic changes (CPE) such as rounding and syncytia with degenerative changes on day 5 post-infection

The disease as well as considerable morbidity and mortality recorded mostly in sheep, could be because of higher population density of sheep in the state than goats. Even though PPR outbreaks occur throughout the year, the incidence is mostly observed from October to March, with a peak during February in Karnataka (Hegde et al., 2009). Movement of animals due to increased sheep trade mainly during these months might be an additional factor for the occurrence of the disease. Cold dry season, with dusty winds further contributes as a risk factor for respiratory tract infection. So, vaccinating the flocks during the months of July to September is reported to be very appropriate (Hegde et al., 2009) targeting naïve lambs and kids above three to four months of age. Intensive vaccination campaign programmes should be taken up on a village / flock basis instead of individual or households as reported earlier (Dilli et al., 2011). On account of regular annual vaccination being carried out in the state from 2011 under NCP-PPR only twenty five to thirty per cent of replaced naïve ones are expected to be at risk of getting infected as reported earlier (Balamurugan et al., 2014b). The successful vaccination programme has also reduced the outbreaks in the states to a considerable level as seen in Figure 5 based on the available data analysis. In this study, we have investigated 12 outbreaks during the period from October, 2014 to December, 2015. However, reported outbreaks data in Karnataka during 201415 (April 14 to March 15) were 16 and during 2015-16 (April 15 to Dec 15) there were 18 reported outbreaks.

Morbidity among these outbreaks was 9 to 44 per cent with an average of 26.89 per cent and mortality was 0 to 36 per cent with an average of 10.90 per cent. Diallo (2006) reported that morbidity and mortality rates due to PPR may vary from 0 to 90 per cent depending on the animal husbandry, breed, age and other factors. Abu Elzein et al. (1990) reported the mortality of 50-90 per cent and sometimes nil, and morbidity of 10 to 100 per cent, and even lower than 10 per cent depending on circumstances. Considerably low morbidity and mortality reported in this study could be due to regular vaccination carried out in the state. It was also elucidated that attenuated PPR vaccine is capable of providing good protection in vaccinated animals which is in accordance with Santhosh et al. (2013). On analysis of the data available, maximum number of outbreaks were recorded during 2005 , later on outbreaks were less due to regular vaccination programme carried out in the state. The outbreaks were least during 2011-12 ( $n=3$ ) and 2013-14 ( $\mathrm{n}=2)$ due to implementation of NCP-PPR. Later on, the disease is very well under control in the state.

The serum samples collected from infected and in contact animals showed varying percentage inhibition (PI) for PPRV antibodies from 2 to 75 by c-ELISA, indicating that the animals were under different stages of infection in different outbreaks. As most of these animals were not vaccinated earlier, the detection of PPRV antibody could have been only resulted from infection with PPRV since the virus is endemic in the Southern part of India (Balamurugan et al., 2014a) including Karnataka.

PPRV antigen was detected by s-ELISA and highly positive samples were subjected for virus isolation in Vero cell lines. The passaged viruses during adaptation showed characteristic CPE of PPRV after 5 to 6 dpi in Vero cells at passage level 4 to 6. Earlier, Balamurugan et al. (2010a) isolated the PPRV from the sheep and goats at earlier passage levels after 4 to 10 dpi in Vero cells from field outbreaks. In this study, the isolates of PPRV were confirmed by RT-PCR, which gave specific amplicon size products with respect to the gene specific sequences (Figure 3). Further characterization of the virus by gene sequencing and phylogenetic analysis is required for the classification of the lineages and to know the circulating virus in the state including current outbreaks. However, so far, the phylogenetic analyses of different isolates including vaccine strains of India has shown only PPRV lineage IV to be in circulation in India since the disease was first reported 


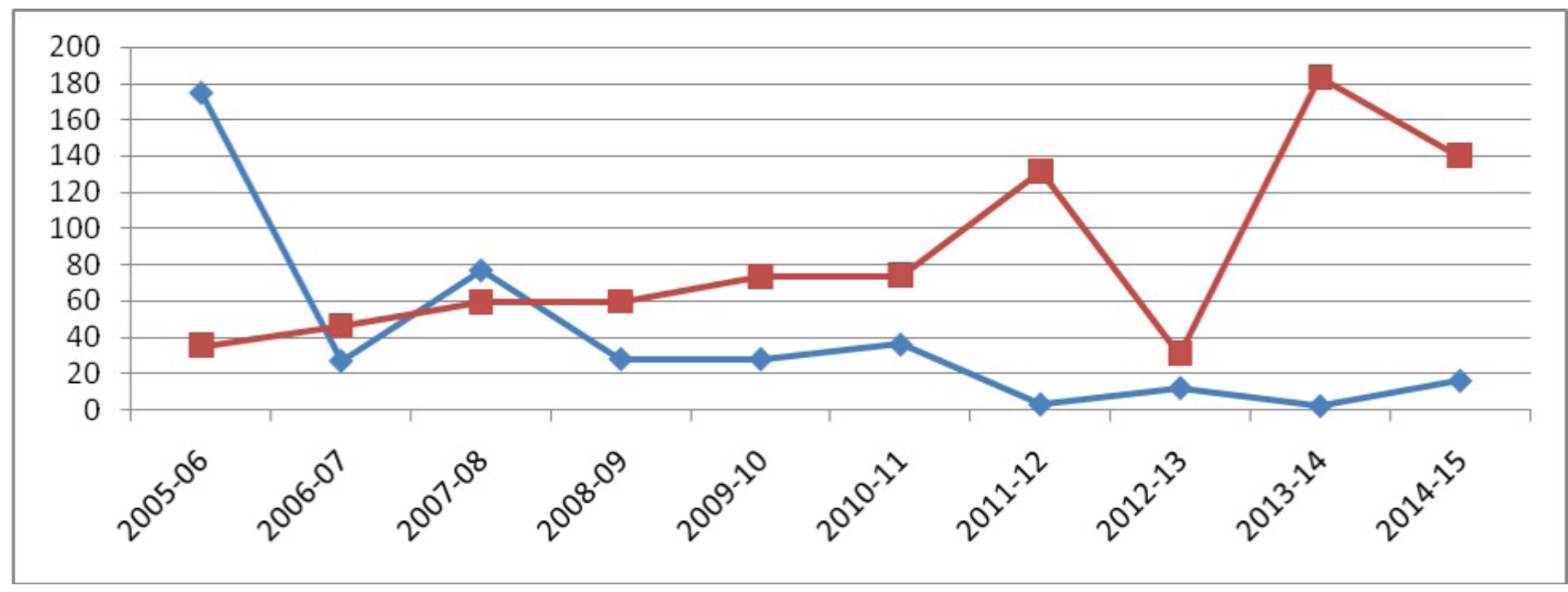

Figure 5: Status of vaccination (red line-in lakh doses) and disease outbreak (blue line-in numbers) in the state of Karnataka from 2005 to 2015

(Shaila et al., 1996; Balamurugan et al., 2010b). In general, the significant epidemiological and socio economic parameters observed include, young animals were affected severely; adult animals showed only a few and milder symptoms of PPR; pattern of the disease is changing with respect to severity of gross lesions and clinical sign; source of infection was from introduction or purchase of animals from other states / flocks; mortality and morbidity was moderate; The economic losses during the current outbreaks were due to death and loss in weight of affected animals; feed and fodder loss due to off feed, wastage, spoilage etc.; spending more labour hours for the maintenance of the affected animals as well as for treatment; delay in recovery of investment, loss due to cost of treatment and vaccination etc. These observations are in accordance with the outbreaks related economic losses reported earlier by Balamurugan et al. (2014b).

In conclusion, the epidemiology of the outbreak, clinical signs, virus isolation, detection of PPRV antigen/antibody by RT-PCR and ELISA assays, and the identity of the virus have confirmed that the outbreaks were caused by PPRV. Due to the importance of PPR and high productivity losses in small ruminants, outbreaks need to be monitored carefully in spite of regular strategic vaccination under NCP-PPR. Farmers and other livestock handlers need to be educated on prevention and control measures such as vaccination of animals at an appropriate time, good hygienic practices, restriction on movement of infected animal, quarantine measures and biosecurity levels within and between flocks/villages. Effective implementation of these practices will definitely help in limiting the spread and severity of PPR outbreaks in Karnataka and in minimizing the economic losses due to PPR.

\section{ACKNOWLEDGEMENTS}

Authors wish to thank Department of Animal Husbandry and Veterinary Services (AHVS) and Field Veterinarian for the kind help rendered during outbreak investigations. The authors also thank the Director and Staff of ICARNational Institute of Veterinary Epidemiology and Disease Informatics (NIVEDI) for their constant support and guidance.

\section{CONFLICT OF INTEREST}

No conflicts of interests are declared by authors for the contents in this manuscript.

\section{AUTHORS CONTRIBUTION}

Amitha Reena Gomes designed and carried out the experiment and prepared the draft manuscript, SM Byregowda, BM Veeregowda and D Rathnamma provided guidance, technical support and edited the manuscript, BM Chandranaik, BP Shivashankar and KC Mallinath carried on outbreak investigations and $\mathrm{V}$ Balamurugan provided guidance, technical support, analysed epidemiological data and edited manuscript.

\section{REFERENCES}

-Abu-Elzein EME, Hassanien MM, Al-Afaleq AI, Abd-Elhadi MA, Housawi FMI (1990). Isolation of Peste des Petits Ruminants from goats in Saudi Arabia. Vet. Rec. 127(12): 309-310

-Balamurugan V, Sen A, Saravanan P, Singh RP, Singh RK, Rasool TJ, Bandyopadhyay SK (2006). One-step multiplex RT-PCR assay for the detection of Peste des Petits Ruminants virus in clinical samples. Vet. Res. Commun. 30(6): 655-666 
http://dx.doi.org/10.1007/s11259-006-3331-3

-Balamurugan V, Sen A, Venkatesan G, Yadav V, Bhanuprakash V, Singh RK (2010a). Isolation and identification of virulent Peste des Petits Ruminants viruses from PPR outbreaks in India. Trop. Anim. Health Prod. 42: 1043-1046 http:// dx.doi.org/10.1007/s11250-010-9527-0

-Balamurugan V, Sen A, Venkatesan G, Yadav V, Bhanot V, Riyesh T, Bhanuprakash V, Singh RK (2010b). Sequence and Phylogenetic Analyses of the Structural Genes of Virulent Isolates and Vaccine Strains of Peste Des Petits Ruminants Virus from India. Transbound. Emerg. Dis. 57(5): 352-364 http://dx.doi.org/10.1111/j.18651682.2010.01156.x

-Balamurugan V, Saravanan P, Sen A, Rajak KK, Venkateshan G, Krishnamoorthy G, Bhanuprakash V, Singh RK (2012). Prevalence of Peste des Petits Ruminants among sheep and goats in India. J. Vet. Sci. 13: 279-85 http://dx.doi. org/10.4142/jvs.2012.13.3.279

- Balamurugan V, Krishnamoorthy P, Raju DSN, Rajak KK, Bhanuprakash V, Pandey AB, Gajendragad MR, Prabhudas K, Rahman H (2014a). Prevalence of Peste des Petits Ruminants virus antibodies in cattle, buffaloes, sheep and goats in India. Virus Dis. 25(1): 85-90 http://dx.doi. org/10.1007/s13337-013-0177-5

- Balamurugan V, Apsana R, Raju DSN, Aabraham S, Reddy MGB, Govindaraj G, Nagalingam M, Hemadri D, Veeregowda BM, Gajendragad MR, Rahman H (2014b). Epidemiological investigation of the Peste des Petits Ruminants outbreaks in Tumkur district, Karnataka, India. J. Path. Res. 3(2): 71-75

- Couacy-Hymann E, Roger F, Hurard C, Guillou JP, Libeau G, Diallo A (2002). Rapid and sensitive detection of Peste des Petits Ruminants virus by a polymerase chain reaction assay. J. Virol. Methods. 100(1): 17-25 http://dx.doi.org/10.1016/ s0166-0934(01)00386-x

-Diallo A (2006). Control of Peste des Petits Ruminants and poverty alleviation. J. Vet. Med. 53: 11-13 http://dx.doi. org/10.1111/j.1439-0450.2006.01012.x

-Dilli HK, Geidam YA, Egwu GO (2011). Peste des Petits Ruminants in Nigeria: A review. Niger. Vet. J. 32(2): 112 119

- Forsyth MA, Barrett T (1995). Evaluation of polymerase chain reaction for the detection and characterisation of rinderpest and Peste des Petits Ruminants viruses for epidemiological studies. Virus Res. 39(2): 151-163 http:// dx.doi.org/10.1016/0168-1702(95)00076-3

- Gargadennec L, Lalanne A (1942). La Peste des Petits Ruminants. Bulletin des Services Zoo-techniques, et des Epizooties de I'Afrique Occid ntale Fran-caise. 5: 16-21

- Govindarajan R, Koteeswaran A, Venugopalan AT, Shyam G, Shaouna S, Shaila MS, Ramachandran S (1997). Isolation of Peste des Petits Ruminants virus from an outbreak in Indian buffalo (Bubalus bubalis). Vet. Rec. 141(22): 573-574 http://

\section{dx.doi.org/10.1136/vr.141.22.573}

- Hegde R, Gomes AR, Muniyellappa HK, Byregowda SM, Giridhar P, Renukaprasad C (2009). A short note on Peste des Petits Ruminants in Karnataka, India. Revue Scientifique et Technique (International Office of Epizootics). 28(3): 1031-1035

-Muhammad A, Syed MJ, Muhammad JA, Manzoor H, Qurban A (2009). Peste des Petits Ruminants virus (PPRV) infection: Its association with species, seasonal variations and geography. Trop. Anim. Health Prod. 41: 1197-1202 http:// dx.doi.org/10.1007/s11250-008-9300-9

-Muse EA, Karimuribo ED, Gitao GC, Misinzo G, Mellau LSB, Msoffe PLM, Swai E S (2012). Epidemiological investigation into the introduction and factors for spread of Peste des Petits Ruminants, southern Tanzania. Onderstepoort J. Vet. Res. 79(2): 6 pages.

- Nanda YP, Chatterjee A, Purohit AK, Diallo A, Innui K, Sharma RN, Libeau G, Thevasagayam JA, Bruning A, Kiching RP, Anderson J, Barrett T, Taylor WP (1996). The isolation of Peste des Petits Ruminants virus from Northern India. Vet. Microbiol. 51(3-4): 207-216 http://dx.doi. org/10.1016/0378-1135(96)00025-9

-Santhosh AK, Gomes AR, Hegde R, Rathnamma D, Veeregowda BM, Byregowda S M, Renukaprasad C, Bhanuprakash V, Prabhudas K, Hegde NR, Isloor S (2013). Comparative immunogenicity of two Peste des Petits Ruminants (PPR) vaccines in South Indian sheep and goats under field conditions. Indian J. Virol. 24(3): 373-379 http://dx.doi. org/10.1007/s13337-013-0168-6

-Shaila MS, Purushothaman V, Bhavasar D, Venugopal K, Venkatesan RA (1989). Peste des Petits Ruminants of sheep in India. Vet. Rec. 125(24): 602-602

-Shaila MS, Shamaki D, Forsyth MA, Diallo A, Goatley L, Kitching RP, Barrett T (1996). Geographic distribution and epidemiology of Peste des Petits Ruminants virus. Virus Res. 43(2): 149-153 http://dx.doi.org/10.1016/01681702(96)01312-3

-Singh RP, Sreenivasa BP, Dhar P, Bandyopadhyay SK (2004a). A sandwich-ELISA for the diagnosis of Peste des Petits Ruminants (PPR) infection in small ruminants using antinucleocapsid protein monoclonal antibody. Arch. Virol. 149(11): 2155-2170 http://dx.doi.org/10.1007/s00705004-0366-z

-Singh RP, Sreenivasa BP, Dhar P, Shah LC, Bandyopadhyay SK (2004b). Development of a monoclonal antibody based competitive-ELISA for detection and titration of antibodies to Peste des Petits Ruminants (PPR) virus. Vet. Microbiol. 98(1): 3-15 http://dx.doi.org/10.1016/j.vetmic.2003.07.007

-Venkataramanan R, Bandyopadhyay SK, Oberoi MS (2005). Present status and strategies for the control of transboundary and other economically important animal diseases in India: a review. Indian J. Anim. Sci. 75: 456-464 